\title{
Congenital Primary Pachydermoperiostosis and Striate Palmoplantar Keratoderma - a Case Report
}

\author{
Slobodan STOJANOVIĆ ${ }^{*}$, Nada VUČKOVIĆ ${ }^{2}$, Marina JOVANOVIĆ ${ }^{1}$, Kosta PETROVIĆ ${ }^{3}$ \\ ${ }^{1}$ Clinic of Dermatovenereology Diseases, Clinical Center of Vojvodina, Faculty of Medicine, University of Novi Sad \\ ${ }^{2}$ Center of Pathology and Histology, Clinical Center of Vojvodina, Faculty of Medicine, University of Novi Sad \\ ${ }^{3}$ Center of Radiology, Clinical Center of Vojvodina, Faculty of Medicine, University of Novi Sad
}

${ }^{*}$ Correspondence:

DE GRUYTER
OPEN

UDC 616.5-002.52:616.594.1

\begin{abstract}
The authors present a rare case of congenital pachydermoperiostosis associated with striate palmoplantar keratoderma in a 55-year-old female. Pachydermoperiostosis (PDP) is a heterogeneous syndrome characterized by hypertrophic changes involving predominantly the skin and bones of the extremities: pachydermia, clubbing of the fingers and toes, and hypertrophic osteoarthropathy. Primary pachydermoperiostosis (Touraine-Solente-Gole syndrome) (PPDP) or primary hypertrophic osteoarthropathy $(\mathrm{PHO})$ is a rare congenital disorder and is one of two types of hypertrophic osteoarthropathy. In addition to the three main criteria, which are confirmed clinically, histologically, and by X-ray, there may be other additional clinical features. Hyperhidrosis of the hands and feet may be troublesome. The skin of the face, forehead and scalp becomes grossly thickened and thrown into folds. The folding of the scalp produces a form of cutis verticis gyrata. Additional clinical features include hypohidrosis, seborrhea, sebaceous gland hyperplasia and folliculitis, carpal and tarsal tunnel syndrome, chronic leg ulcers and calcification in the Achilles tendon. Our patient presented with most of these additional clinical features, such as acro-osteolysis of the fingers and toes, which generally occurs occasionally. In regard to palmoplantar keratoderma, we have not found reports of its association with PPDP in the available literature.

Unlike PPDP, secondary pachydermoperiostosis (secondary hypertrophic osteoarthropathy -SHO) occurs in association with severe pulmonary disease such as bronchiectasis, abscess, bronchial carcinoma, pleural mesothelioma, or thymic, esophageal or stomach cancer, which were all excluded in our patient.

In conclusion, this paper presents a congenital form of pachydermoperiostosis in a female also suffering from striate keratoderma. According to the available literature, this is the first case report of comorbidity between these two dermatoses.
\end{abstract}

\section{Key words}

Osteoarthropathy, Primary Hypertrophic; Keratoderma, Palmoplantar; Diagnosis; Signs and Symptoms; Comorbidity

$\mathrm{P}$ achydermoperiostosis (PDP) is a heterogeneous syndrome characterized by hypertrophic changes involving predominantly the skin and bones of the extremities: pachydermia, clubbing of the fingers and toes and hypertrophic osteoarthropathy $(1,2)$. Primary pachydermoperiostosis (Touraine-SolenteGole syndrome) (PPDP) or primary hypertrophic osteoarthropathy (PHO) is a rare inherited disorder with no hard evidence of inheritance related to $\mathrm{X}$ chromosome: in some families, autosomal dominant inheritance with incomplete penetrance and variable expressivity was detected, while in other families, autosomal recessive inheritance has been demonstrated $(1,3)$. In 2008 , the primary genetic defect in this disease was mapped to chromosome 4q33-q34 identifying mutations in the HPGD gene, encoding the NAD+dependent 15-hydroxyprostaglandin dehydrogenase (3). This is the main enzyme of prostaglandin degradation, so homozygous individuals with truncating mutations of HPGD may also have persistent patent ductus arteriosus, secondary to the elevated levels of prostaglandin, while mild clubbing of the digits can be present in heterozygous carriers of HPGD mutations (3). 
The three major criteria of this syndrome include pachydermia (thickening of the skin), hypertrophic osteoarthropathy with periostitis (excessive bone formation) and the so-called "clubbing" (swelling of the soft tissues of the terminal phalanx of a digit that obliterates the angle between the base of the nail and the digit) with idiopathic acromegaloid features $(1,4)$. It has a marked predominance in males (5).

The authors present a rare case of congenital pachydermoperiostosis associated with palmoplantar keratoderma in a 55-year-old female.

\section{Case report}

A 55-year-old female with a lifelong history of clubbing of the fingers and a diagnosis of congenital pachydermoperiostosis was first referred to our Clinic in 2011. The diagnosis was made in childhood by a physiatrist, based on x-rays, but since then the patient was not treated or examined thoroughly. On admission, she complained of pain in muscles and joints, especially in the small joints of the hands and feet, as well as of toenail changes and inability to stand on a flat surface, forcing her to wear high heels. Over the last ten years she noticed yellowish thickening of the skin on the palpms and feet with nail damage and deformities of the fingers and toes. She experienced walking difficulties and pain in the joints of knees, feet, and along the lumbosacral spine.

History data showed that during childhood the patient was admitted to the Endocrinology Department of the Institute for Mother and Child Health Care in Novi Sad on two occasions, and at the Institute of Internal Medicine in Novi Sad 20 years ago.

Based on the submitted data, we learned that she underwent benign breast tumor surgery in 2003, and had regular 6-month check-ups with her oncologist: an intraductal papilloma was removed from the left, and an atheroma from the right breast. The following check-ups indicated removal of new tumors in both breasts, and after magnetic resonance imaging and histopathological analysis, the diagnosis of fibro-micro-cystic dysplasia/ adenosis without extensive changes was made; 6-month check-ups with her oncologist continued.

Patient data also revealed that a tumor was removed from the palm of her right hand in 2008, histologically consistent with intradermal pigmented nevus and syringoma. Due to a reduced passive and active mobility of the right hand, electromyography test showed: axonal moderate to severe lesion of the $\mathrm{C} 8$, Th1 right-sided miotomes; no signs of acute injury, corresponding to radicular syndrome. X-ray examination showed diffuse osteoporosis of the hands, feet and knee joints. Bone mineral density (BMD) was measured by dual-energy $\mathrm{X}$-ray absorptiometry (DEXA) and spinal osteoporosis was excluded.

Apart from this, it was found that the patient was treated by a cardiologist for compensated cardiomyopathy.

The family history revealed that her father's mother suffered from "arthritis" and changes similar to hers, and that her father died of a myocardial infarction.

On the first visit, general physical examination showed that the patient was in good general condition, but having mobility difficulties. The pertinent findings were confined to the skin of palms and soles, fingers, toes and nails as well as bones and joints on the hands and feet: hyperkeratosis on the palms and soles with a clinical picture of palmoplantar striate keratoderma (Figures $1,2)$; signs of hypertrophic osteoarthropathy on the fingers with clubbing of the nails (Figure 3); subungual hyperkeratosis of the toenails and hands with thickened, dystrophic dark yellow nail plates and onycogryphosis (Figure 4); inguinal follicular hyperkeratosis; keratotic thickened skin around the Achilles tendons and swelling of the ankles.

\section{Investigations}

Laboratory tests revealed the following abnormal test results: sedimentation rate $44 / 74 \mathrm{~mm} / \mathrm{h}$, red blood cell count 3.19 x1012/L, hemoglubin: $10.5 \mathrm{~g} / \mathrm{L}$, osteocalcin: $54.3 \mathrm{ng} / \mathrm{ml}$ (normally 12-41 ng/ml), Cross Laps: 572 $\mathrm{pg} / \mathrm{ml}$ (normally $162-436 \mathrm{pg} / \mathrm{ml}$ ).

Affected skin samples were positive for: Klebsiella pneumoniae, Pseudomonas aeruginosa, and Stenotrophomonas maltophiia, which are sensitive to several antibiotics.

Mycological examination: Candida albicans was isolated between the toes of both feet.

Oncomarkers: The following serum levels of tumor markers were estimated: carcinoembryonic antigens (CEA) 9,7 ng/ml (normally < 5,0 ng/ml), alpha fetoprotein antigens (AFP), CA 19-9 carbohydrate antigen, CA 15-3 carbohydrate antigen, and CA 125 carbohydrate antigen were all within normal levels.

$\mathrm{X}$-ray of the hands, feet and long bones: Prominent diffuse osteoporosis. Hand X-ray: bilateral narrowing of the proximal interphalangeal joint space, pronounced on the third, fourth and fifth fingers on the right hand, and 


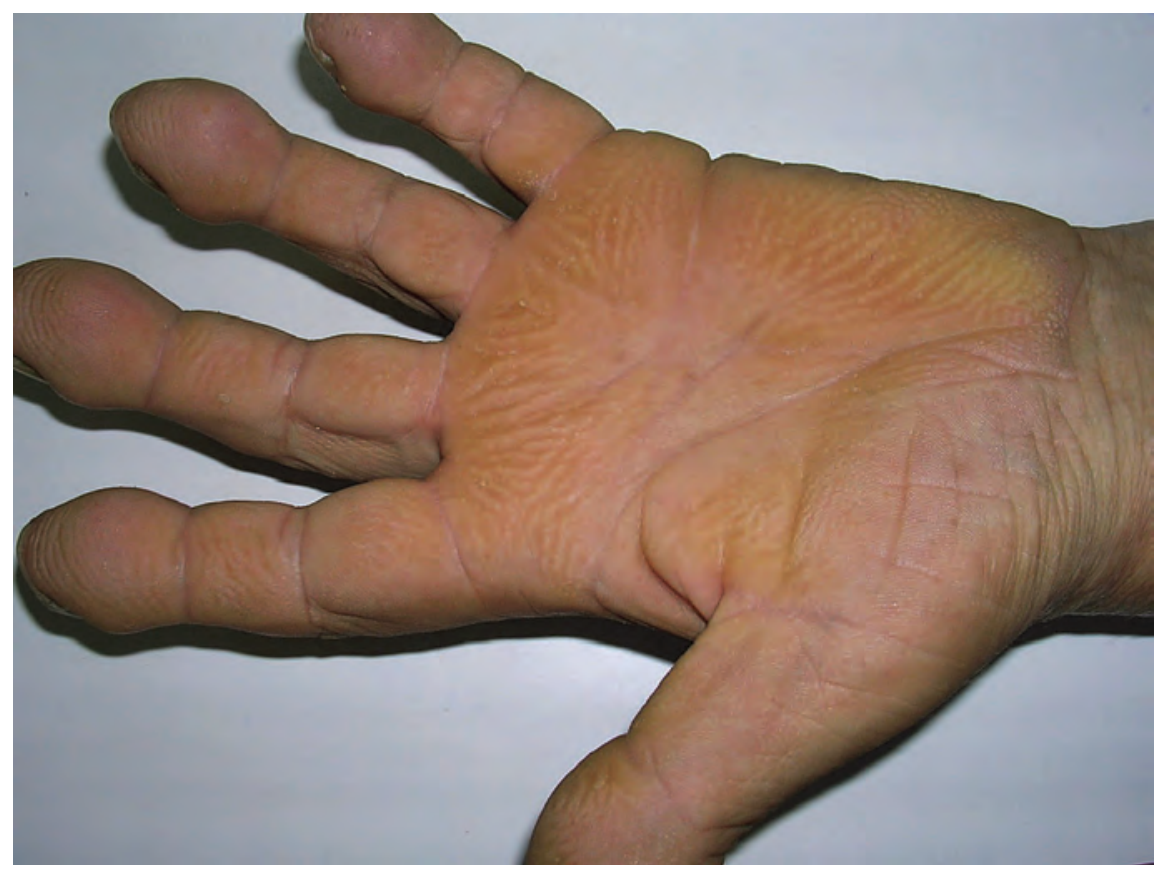

Figure 1. Striate palmar keratoderma with pachyonyichia

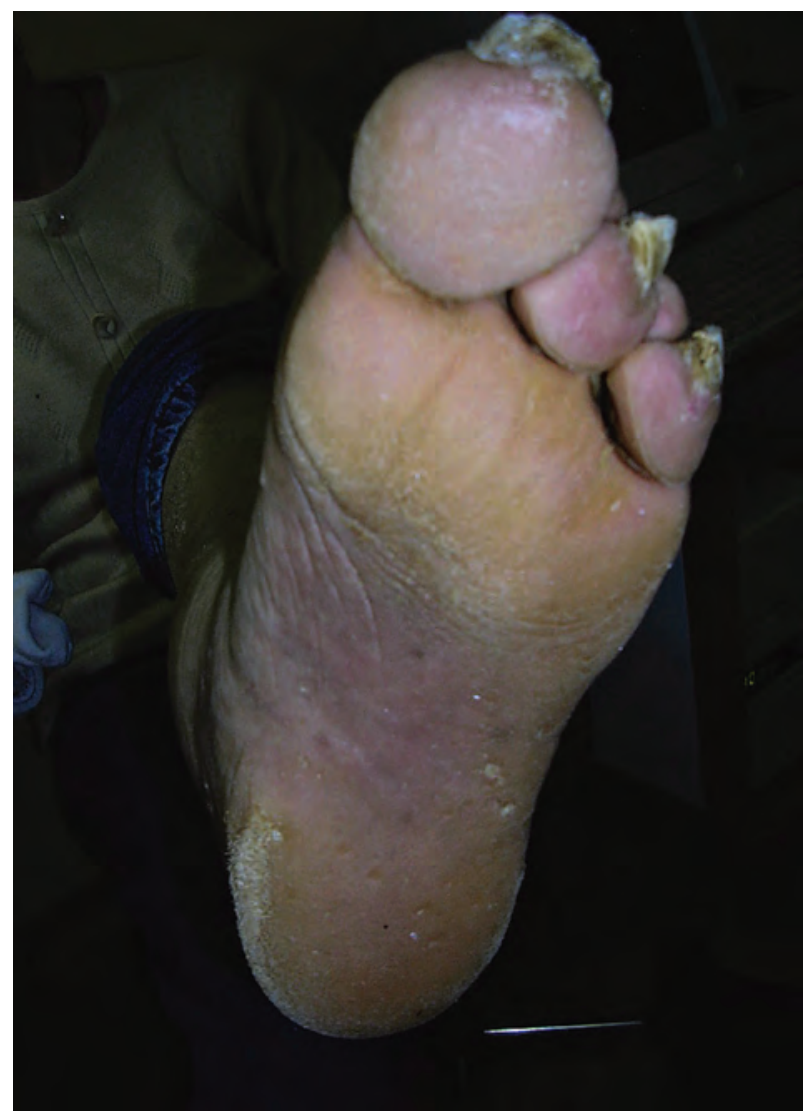

Figure 2. Plantar keratoderma with subungual hyperkeratosis and onychogryphosis on the fift finger on the left hand; marked narrowing of the distal interphalangeal joint space, with subluxation of the distal phalanges of the fifth finger of the right hand; acro-osteolysis of distal phalanges present on all fingers, with almost complete lysis of the distal phalanges of the fifth finger of the left hand; edema of the surrounding soft tissue - clubbing fingers (Figure 5).

X-ray of the feet: Bilateral talocrural joint and metatarsophalangeal joint space narrowing of the first toe; acro-osteolysis of distal phalages present on all toes, with nearly complete lysis of ditstal phalanges of the fifth, third toes of the left foot, and on the third, fourth and fifth toes of the right foot; bilateral periosteal reaction of the calcaneus and the first metatarsal bone, more prominent on the right foot; rough exostoses on the distal heads of the first metatarsal bone of both feet; bilateral calcaneal spurs at the site of the insertion of the plantar aponeurosis of the Achilles tendon, more pronounced on the right foot (Figure 6).

$\mathrm{X}$-ray of long bones: Bilateral periosteal reaction in the tibia, fibula with bone bridge formation (Figure 7).

X-ray of the knee and long bones: Marked diffuse osteoporosis; bilateral asymmetric narrowing of the joint space of the tibiofemoral joint, prominent laterally with a lateral notch, and intercondylar eminences and subchondral sclerosis of the articular surfaces; periosteal reaction of both the femur(with a 


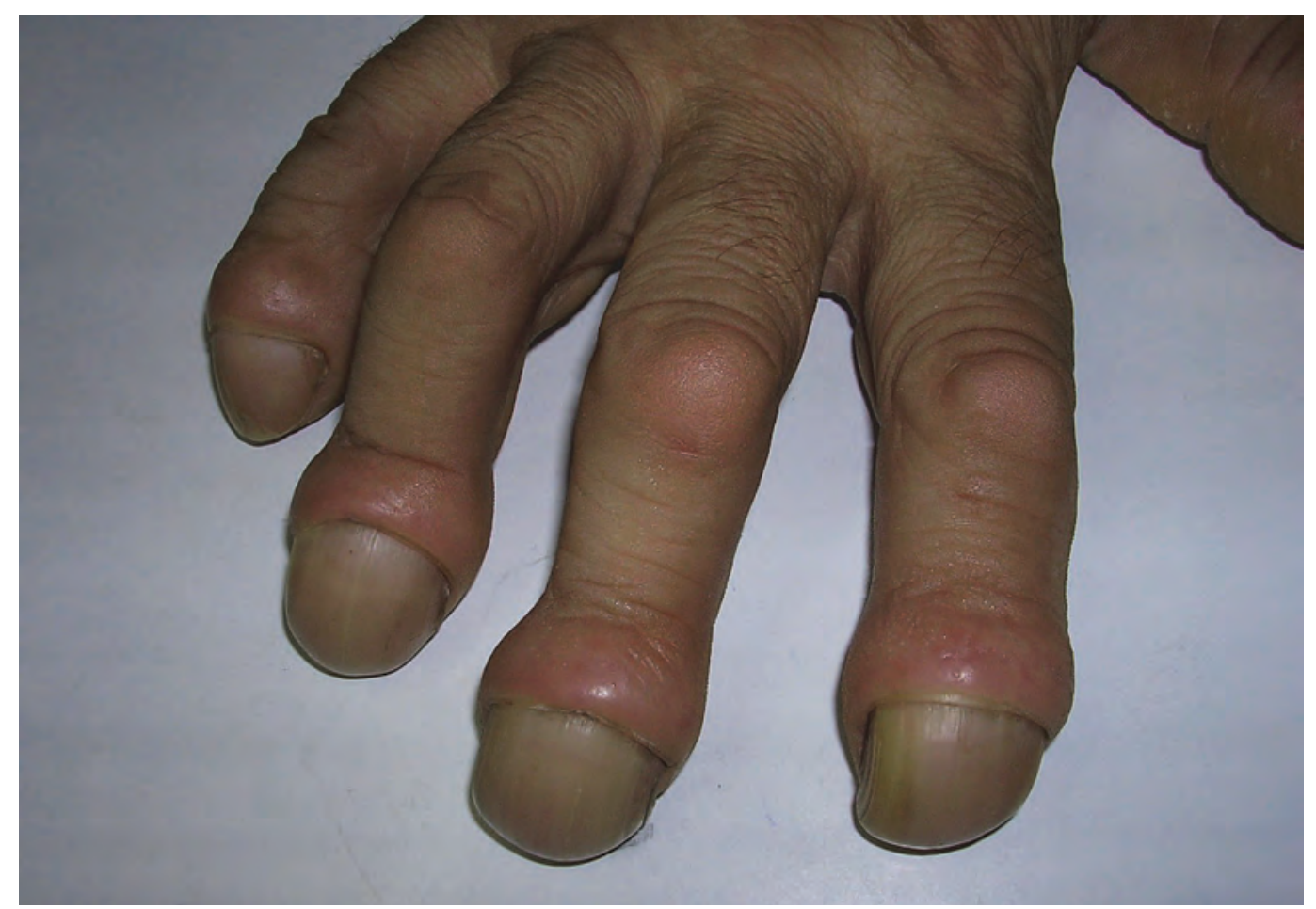

Figure 3. Clubbed fingers (digiti hippocratici) with osteohypertrophic arthropathy

"sunburst" appearance), including the tibia and fibula; calcification in the knee pits; bilateral narrowing of the patellofemoral joint (Figure 8).

Lumbosacral spine $\mathrm{X}$-ray: Corrected physiological lordosis of the lumbar spine, with a sharp transition
- sacrum acutum; intervertebral disc space height and configuration of the lumbar spine preserved. Incidental finding: abdominal aortic calcification; calcified fibroid in the small pelvis.

Mammography in two directions: Predominantly

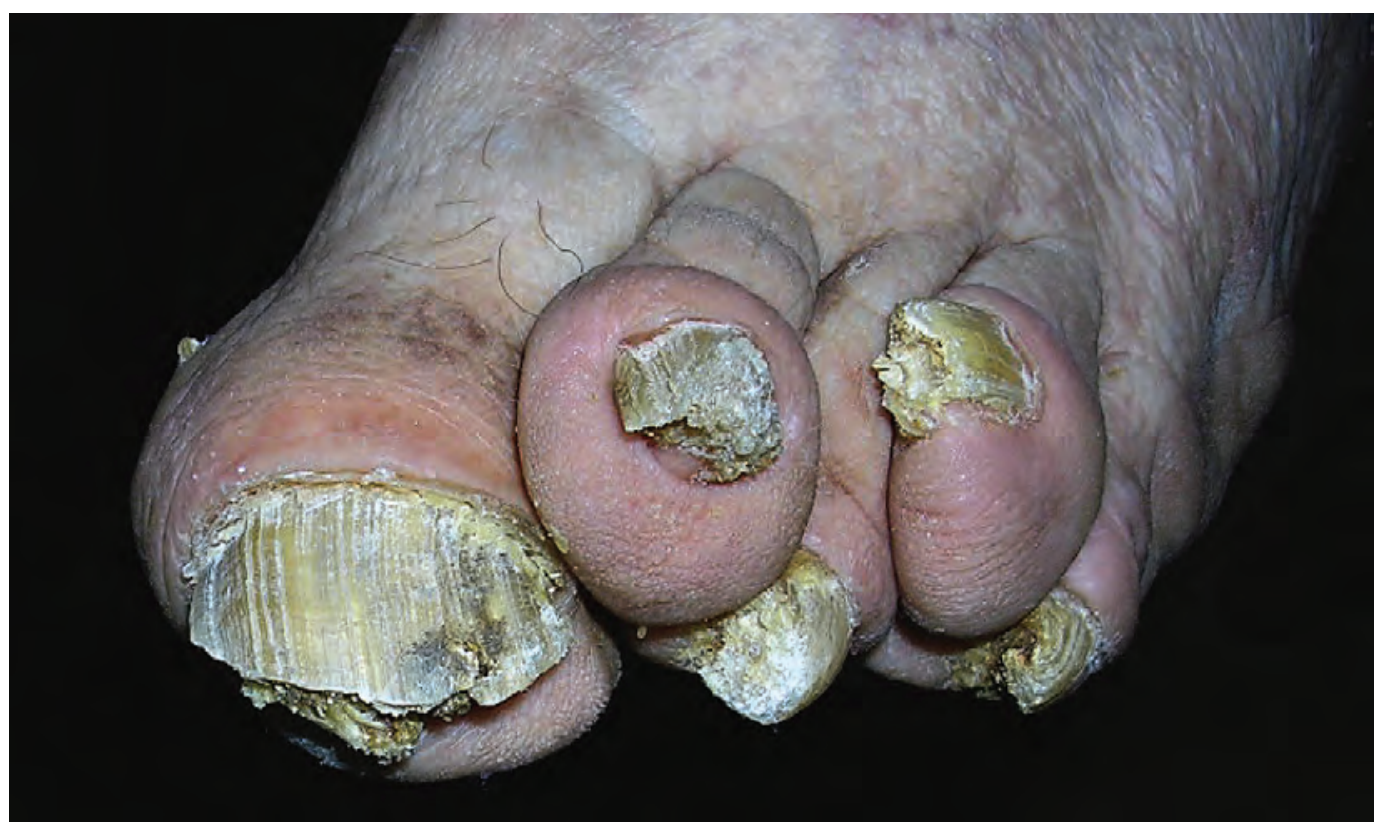

Figure 4. Subungual hyperkeratosis with onychogryphosis and osteoarthropathic foot deformity 


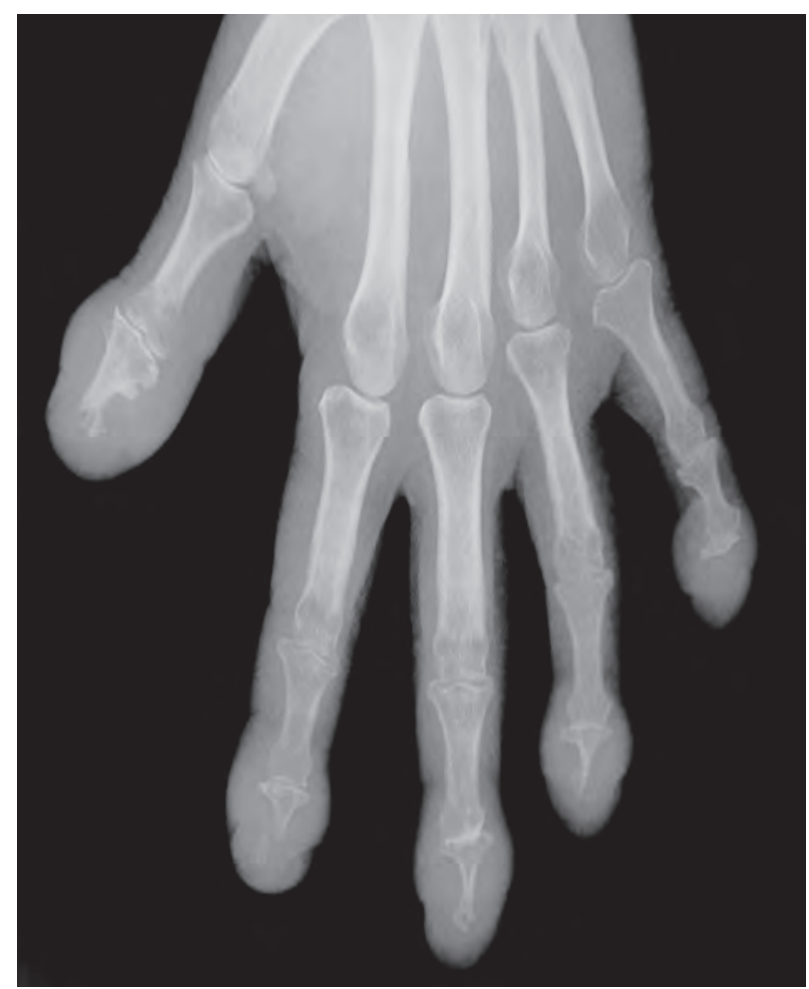

Figure 5. X-ray of the left hand: clubbing of the digits with acrolysis of the distal phalanges; distal phalange of the fifth finger with prominent lysis; visible bone fragments in the soft tissue of the second finger after acrolysisdeformity

fibroglandular tissue in both breasts; perimammilar area of the left breast presents with thickened skin, while grouped polymorphic microcalcifications are present in the retromammary region; oval, vaguely demarcated condensed parenchyma observed in the

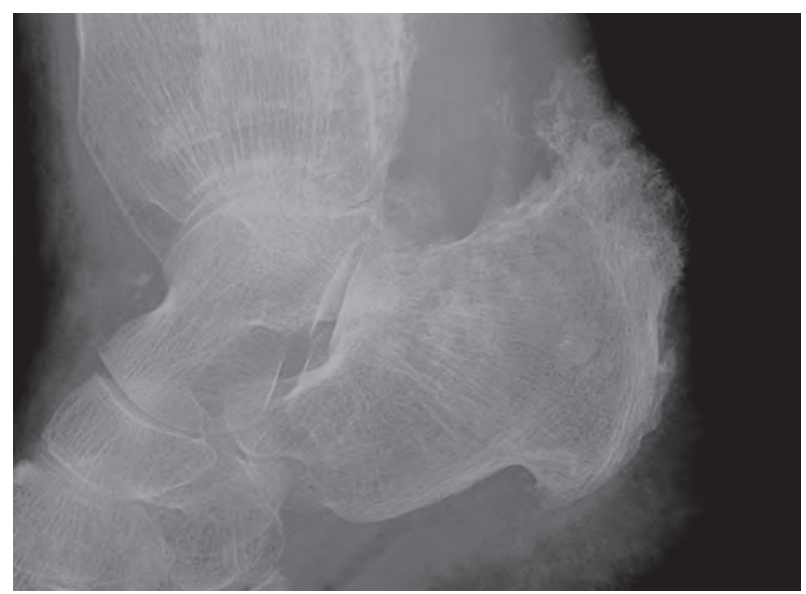

Figure 6. X- ray of the right calcaneus: rough periosteal bone deposits along the edge of the calcaneus

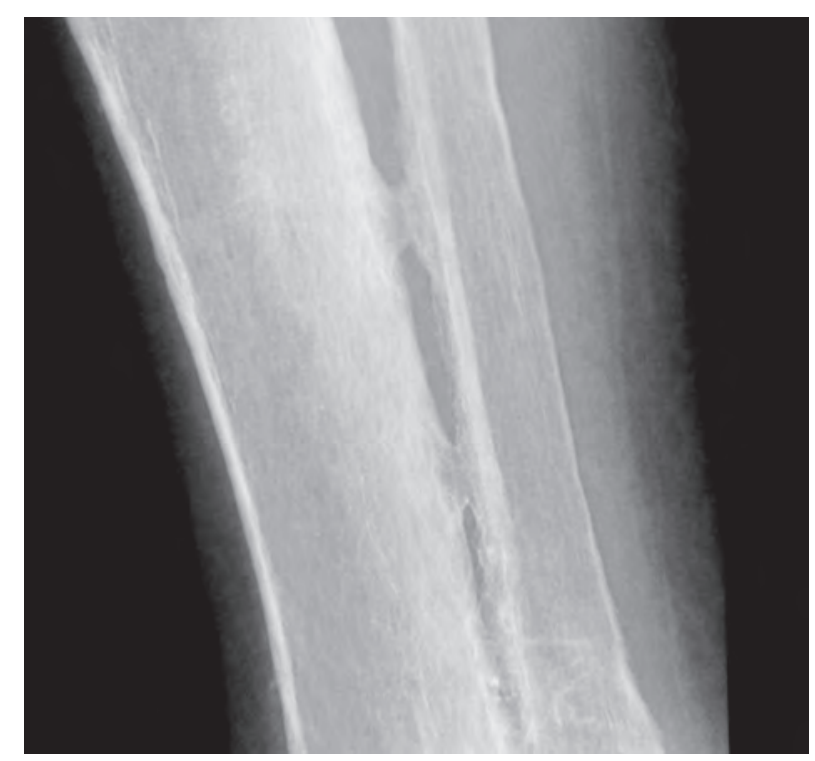

Figure 7. X-ray of the left calf: pronounced periosteal deposits on the tibia and fibula with bone bridge formation

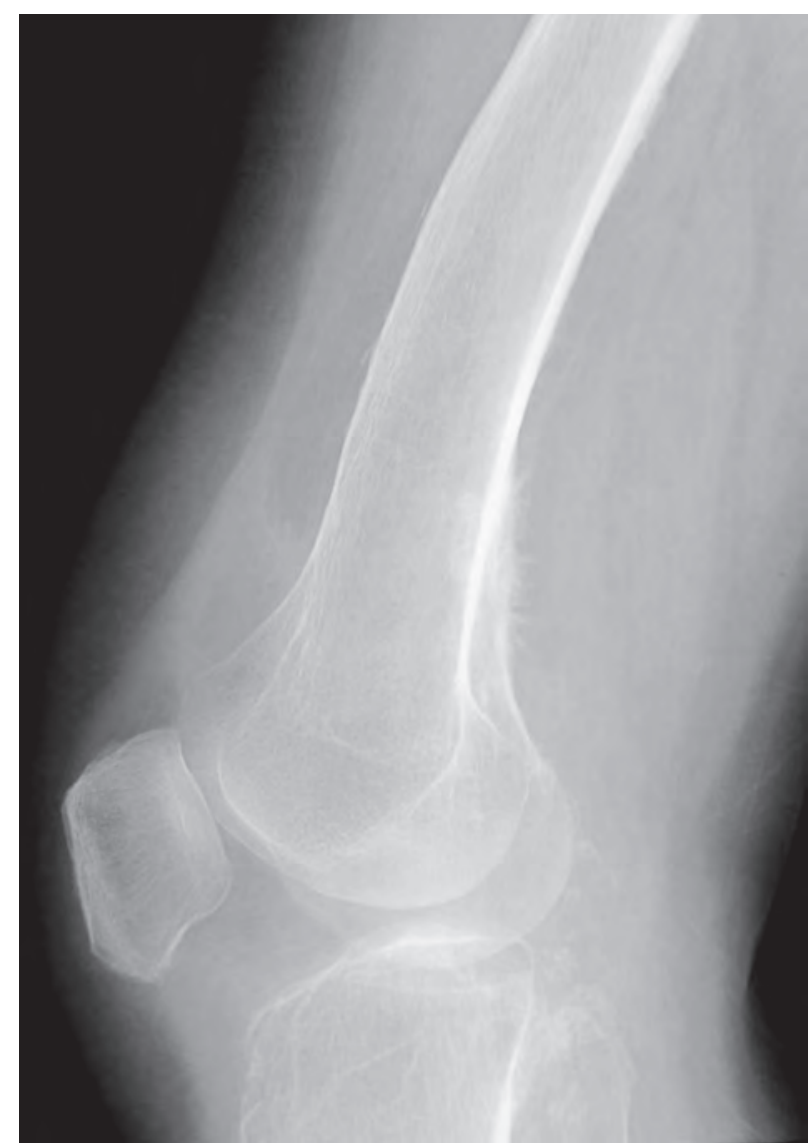

Figure 8. X-ray of the right femur: a periosteal reaction with a "sunburst" appearance 


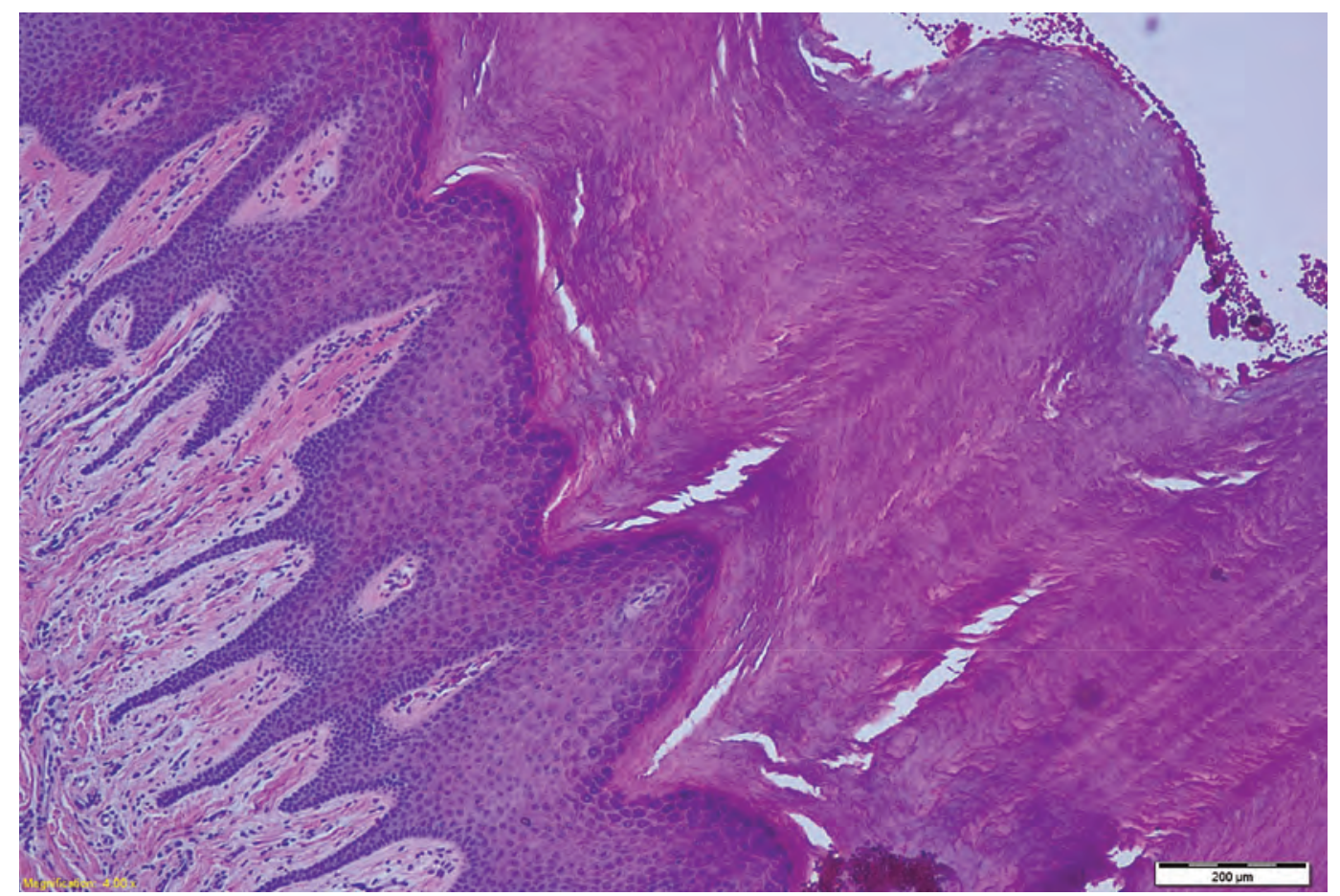

Figure 9. Photomicrograph of the skin with a thick keratotic layer, moderately thick granular layer of the epidermis and mild acanthosis and papillomatosis (HE x 40)

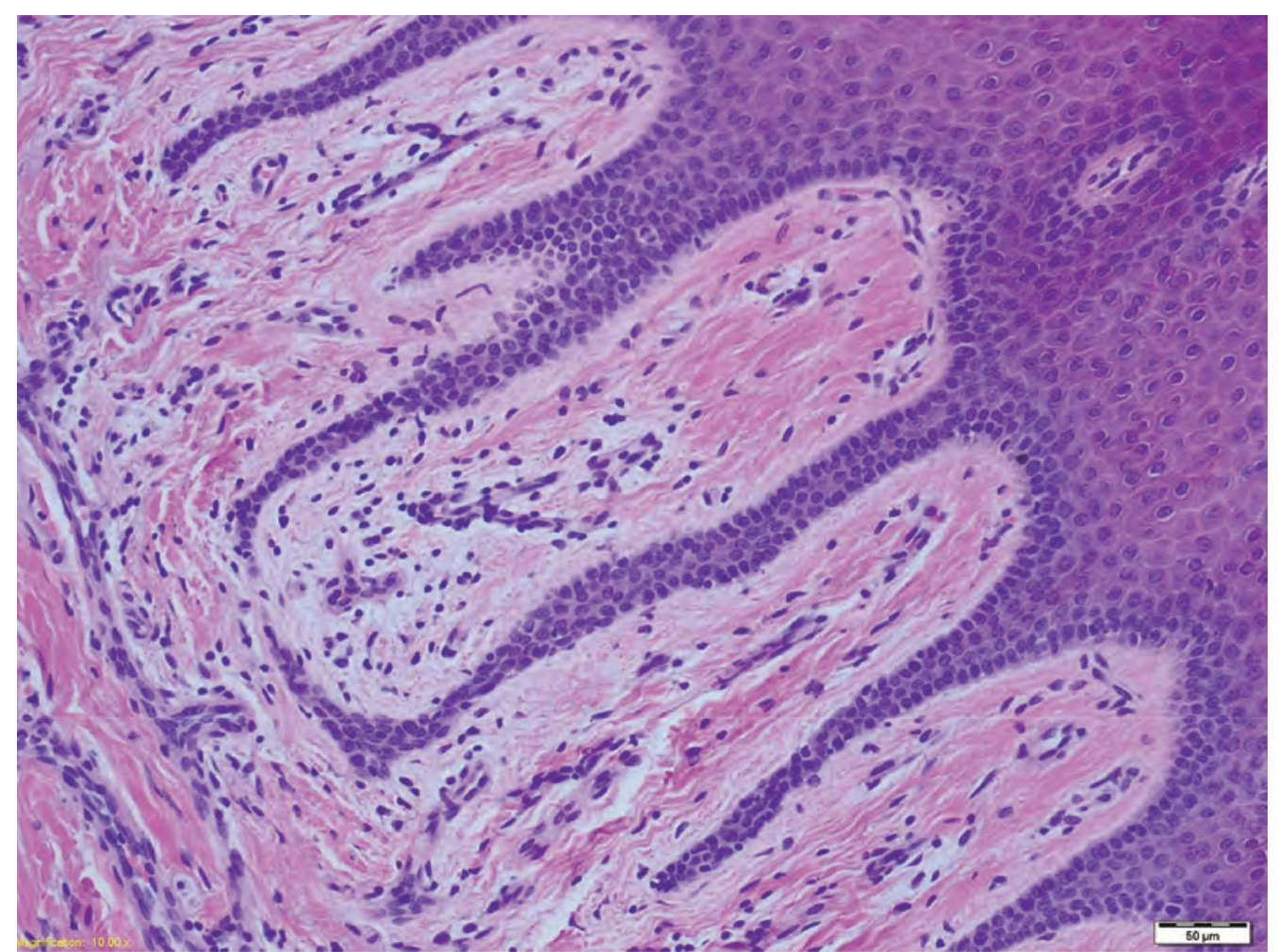

Figure 10. Photomicrograph of a skin biopsy specimen with moderately elongated epidermal papillae and thickened collagen fibers in the papillary dermis (HE x 100) 
center line requiring ultrasound evaluation; there are no tumor shadows in the right breast, nor pathognomonic microcalcifications; no visible axillary node enlargement. Breast ultrasound: A round cyst $14 \times 9 \mathrm{~mm}$, along with a smaller one $6 \mathrm{~mm}$ in diameter, were found in the retroareolar region of the left breast; moderate duct ectasia; no visible signs of pathological condensation of breast parenchyma; the right breast presented with sporadic microcysts up to $5 \mathrm{~mm}$ in diameter; axillary fibrolipomatous lymph nodes.

Chest X-ray finding (PA): Normal. Gastroduodenal X-ray finding: Normal.

Upper abdomen X-ray: Signs of gallbladder polyps and cholesterolosis. Uterus myomatosus was an incidental finding. Findings on the liver, pancreas, and kidneys were normal.

Thoracic CT (native): Normal.

Arterial and venous duplex ultrasound of the lower extremities: Normal findings on the arteries and veins, with a slightly pronounced Cockett's perforator on the left leg; enlarged lymph nodes visible bilaterally in the proximal part of the thigh; distal soft tissue swelling below the knee, more pronounced on the left leg.

Histological findings of palmar keratoderma (thenar of the left hand from May 27, 2011; PH finding no.13072/11): pronounced hyperkeratosis of the epidermis with acanthosis (Figure 9); a prominent granular layer and regularly elongated rete ridges; moderate edema of the papillary dermis; collagen fibers are tough and the dermis is slightly thickened (Figure 10); septa of the subcutaneous adipose tissue are extremely visible and thick; sweat glands are normal. Conclusion: Cutaneous and subcutaneous changes are consistent with pachydermoperiostosis.

Specialist consultations: Otorhinilaryngologist, dentist, gynecologist, gastroenterologist, cardiologist, ophthalmologist, pulmonologist, physiatrist.

Otorhinolaryngologist: Hypoacusis mixta gradus levis. No focus. Bilateral light mixed hearing loss $-25 \mathrm{~dB}$.

Gynecologist: Menopause - the last cycle in 2009. Postmenopause. Myoma uteri. Other findings - normal.

Dentist: Periodontal disease.

Ophthalmologist: Normal.

Endocrinologist: Dual-energy X-ray absorptiometry

(DEXA) - indicates left hip osteoporosis.

Vascular surgeon: Feet problems are not vascular in nature. Orthopedic surgeon: contractura genus bilateralis gravis.

Cardiologist: Chronic cardiomyopathy.
Pulmonologist: No pulmonary fibrosis. Recommendation - 6-month check-up.

Radiologist: Skeletal X-rays revealed changes, predominantly in the long bones, hands and feet consistent with severe pachydermoperiostosis.

Physiatrist: Orthopedic shoes with a platform are recommended. Postural imbalance is part of the underlying disease; clubbing fingers - functional. Scoliosis - T4L, the right leg is longer, the right hip is higher set; contracture of the right knee, swelling of both lower legs; impaired walk.

\section{Therapy}

The proposed treatment with systemic and local retinoids was rejected by the patient. After the potential chronic and malignant causes of secondary hypertrophic osteoarthropathy were excluded, nonsteroidal antiinflammatory drugs (NSAID) and local keratolytic treatment was initiated, as well as Tamoxifen, an anti-oestrogenic drug which may be useful in the treatment of fibrocystic disease of the breast, prescribed by the gynecologist.

\section{Discussion}

Primary pachydermoperiostosis (PPDP), or primary hypertrophic osteoarthropathy $(\mathrm{PHO})$, is a rare inherited disorder with a characteristic triad: clubbing of the fingers and toes, periostosis, and pachydermia $(1,3)$, as well as elevated levels of prostaglandin E2 (PGE2), which can be considered as a consequence of cytokine-mediated tissue remodeling and vascular stimulation. In $\mathrm{PHO}$, these effects are associated with hyperhidrosis, acroosteolysis, pachydermia, periostosis and arthritis (6,7). PGE2 may affect the activity of osteoblasts and osteoclasts (ie promote osteoclasia). For these reasons, acroosteolysis and periosteal new bone formation are explained by effects of PGE2 (8). Moreover, PGE2 has vasodilator effects, which is consistent with prolonged local vasodilation in clubbing fingers (8). Apart from elevated levels of PGE2, studies including patients with PDP showed increased plasma levels of several other mediators, such as von Willebrand factor, and vascular endothelial growth factor (VEGF) $(1,9)$. These mediators play a significant role in PDP progression and periosteal proliferation (1). Unlike mutations in 15-hydroxyprostaglandin dehydrogenase (HPGD), mutations in the genes encoding synthesis of these factors have not been established so far $(1,9)$.

PPDP is one of the two types of hypertrophic osteoarthropathy. It represents approximately $5 \%$ of 
the total hypertrophic osteoarthropathy cases with a prevalence of $0.16 \%(4,10)$. Contrary to PPDP, secondary pachydermoperiostosis (secondary hypertrophic osteoarthropathy - SHO) occurs in patients with severe pulmonary diseases such as bronchiectasis, lung abscess, bronchial carcinoma, pleural mesothelioma, or thymic, esophageal and stomach cancer. The bone changes are often painful, develop rapidly and are usually presented as a pertinent finding. Skin changes may be absent or mild. The bone and skin changes regress after appropriate treatment of the primary disease (2). Our case report is about a patient with a congenital hypertrophic osteoarthropathy, without signs of malignancy or cardiopulmonary conditions that might have caused it.

Based on the phenotypic expression, three clinical subtypes of PDP have been proposed: 1) a complete form, presenting the full-blown phenotype which includes all thus far described signs ad symptoms of PDP, but necessarily pachydermia, periostosis and clubbing fingers; 2) an incomplete form, accounting for $54 \%$ of cases with isolated bone involvement, limited skin changes, while pachydermia is less pronounced; 3) a fruste form, which accounts for only $6 \%$ of cases with pachydermia and minimal or absent periostosis (1). The cause of different forms of the disease is unknown (1). In our case, it was a complete phenotype associated with striate palmoplantar keratoderma. Pachydermoperiostosis has a familial aggregation in 25 to $38 \%$ of cases (5), but it has not been verified in our case. Autosomal dominant model with incomplete penetrance, with extremely variable expression, has been proved in about half of the families with incomplete type of the disease (1). Several families with confirmed autosomal recessive model of inheritance, presented with a complete phenotype with severe osteo-skeletal and cutaneous manifestations. Considering the fact that medical history data indicated the existence of the disease only in her father's mother, our patient can be included in the group with a recessive model of inheritance.

Pachydermoperiostosis is clinically diagnosed if the following symptoms are present: pachydermia, clubbing of the fingers and toes, and periostosis (predominantly affecting the distal ends of long bones) $(1,12,13)$. New bone formation is seen on long bone X-rays as symmetrical, irregular periosteal ossifications (13). Digital clubbing is associated with cylindrical thickening of the legs and forearms. Acroosteolysis of the fingers and toes, which may occasionally occur, was also present in our patient. The skin of the hands and feet is also thickened, but usually not folded. Hyperhidrosis of the hands and feet may be troublesome. The skin of the face, forehead and scalp becomes grossly thickened and thrown into folds. The folding of the scalp may produce one of the forms of cutis verticis gyrata. Additional clinical features include hypohidrosis, seborrhoea, sebaceous gland hyperplasia and folliculitis, carpal and tarsal tunnel syndrome, chronic leg ulcerations and calcification in the Achilles tendon. Our patient presented with most of the additional clinical features.

Skin biopsy is another way to diagnose PDP. Histology shows cutaneous sclerosis and hyalinosis, with perivascular infiltration of lymphoid cells in the dermis (5); apart from hypertrophy of collagen and epidermal appendages, an increase of acid mucopolysaccharides may also be seen (2). However, it is not an absolutely specific finding, because changes similar to those in PDP may be found in some other diseases such as myxedema, hypothyreoidism, acromegaly (4). However, skin biopsy helps to diagnose PDP in patients with skin manifestations $(4,14)$. Histological tests of skin samples taken from palms with changes in the dermis and subdermis that match pachydermoperiostosis confirmed the clinical diagnosis of palmoplantar keratodrma and pachydermoperiostosis.

In order to diagnose PPDP, other diseases often need to be excluded. For example, secondary hypertrophic osteoarthropathy must be excluded, as well as cardiovascular, pulmonary, hepatic, intestinal and mediastinal diseases (12). In differential diagnosis, detailed hormone tests are necessary (eg. thyrotropin and growth factor levels), and they were carried out in our patient. In our case thyroid gland disorders were excluded.

In regard to the course and prognosis of PPDP, skin and bone manifestations tend to progress for 5-20 years before stabilizing. Life expectancy may be the same, regardless of the fact that many patients have functional and esthetic complications, including restriction of movements, neurological manifestations and the lionlike appearence with facial folds (leonine facies) $(1,15)$.

Non-steroidal anti-inflammatory drugs (NSAID) are employed as symptomatic treatment, while corticosteroids are used to relieve inflammation and pain. By inhibition of cyclooxygenase enzymes, NSAIDS reduce prostaglandin levels. Other medications are used to improve skin manifestations of patients with PPDP (5). Retinoids are preferably used to improve skin lesions (5). By their systemic action on nuclear receptors of 
skin cells and sebaceous glands, retinoids regulate gene transcription resulting in the following: apoptosis in sebaceous glands (isotretinoin shows favorable cosmetic results) (16), and inhibition of connective tissue and sebaceous glands hyperplasia (17). Retinoids have been shown to reduce procollagen production by diminishing procollagen mRNA in fibroblasts, thus inhibiting the production of collagenase and improving skin lesions in pachydermia: fibroblast biosynthetic activity in the skin lesions of pachydermoperiostosis demonstrates an alteration which may be responsible, at least partly, for the patient's phenotype (1a). Infliximab, tumor necrosis factor alpha (TNF-alpha) inhibitor, may be effective in the resorption of newly formed bones (18). Surgical treatment has been mainly focused on cosmetic and functional improvement (19).

As far as palmoplantar striate keratoderma is concerned, we have not found its association with PPDP in the available literature. Barraud-Klenovsek et al. reported a case of a 30-year-old woman with palmoplantar keratoderma and clubbing of the fingers in 1997 (20). Recently, Perić et al, reported a case of pachydermoperiostosis in a patient with psoriasis (21).

\section{Conclusion}

This paper presents a congenital form of pachydermoperiostosis in a female patient who developed striate keratoderma. According to the available literature, this is the first case report of comorbidity between these two dermatoses.

\section{Abbreviations}

PDP - pachydermoperiostosis

PPDP - primary pachydermoperiostosis

PHO - primary hypertrophic osteoarthropathy

SHO - secondary hypertrophic

osteoarthropathy

CEA - carcinoembryonic antigen

CA - carcino antigen

NAD - nicotinamide adenine dinucleotide

BMD - bone mineral density

DEXA - dual-energy X-ray absorptiometry

NSAID - nonsteroidal antiinflammatory drugs

PGE2 - prostaglandin E2

VEGF - vascular endothelial growth factor

TNF-alpha - tumour necrosis factor alpha

\section{References:}

1. Castori M, Sinibaldi L, Mingarelli R, Lachman RS, Rimoin DL, Dallapiccola B. Pachydermoperiostosis: an update. Clin
Genet 2005;68:477-86.

2. Irvine AD, Mellerio JE. Genetics and genodermatoses. In: Burns T, Breathnach S, Cox N, Griffith SC, editors. Rook's textbook of dermatology. 8th ed. Oxford: Blackwel Publishing; 2010. p. 15.1-97.

3. Uppal S, Diggle CP, Carr IM, Fishwick CW, Ahmed M, Ibrahim $\mathrm{GH}$, et al. Mutations in 15-hydroxyprostaglandin dehydrogenase cause primary hypertrophic osteoarthropathy. Nat Genet 2008;40(6):789-93.

4. Martínez-Ferrer, Peris P, Alós L, Morales-Ruiz M, Guañabens N. Prostaglandin E2 and bone turnover markers in the evaluation of primary hypertrophic osteoarthropathy (pachydermoperiostosis): a case report. Clin Rheumatol 2009;28:1229-33.

5. Gómez Rodríguez N, IbánezRuán J, González Pérez M. Primary hypertrophic osteoarthropathy (pachydermoperiostosis). Report of two familial cases and literature review. Rheumatol Clin 2009;5(6):259-63.

6. Bergmann C, Wobser M, Morbach H, Falkenbach A, Wittenhagen D, Lassay L, et al. Primary hypertrophic osteoarthropathy with digital clubbing and palmoplantar hyperhidrosis caused by 15 PGHD/HPGD loss-of-function mutations. Exp Dermatol 2011;20:531-3.

7. Dabir T, Sills AM, Hall CM, et al. Cranio-osteoarthropathy in sibs. Clin Dysmorphol 2007;16:197-201.

8. Yüksel-Konuk B, Sırmacı A, Ayten GE, Özdemir M, Aslan $\dot{I}$, Yılmaz-Turay Ü, et al. Homozygous mutations in the 15-hydroxyprostaglandin dehydrogenase gene in patients with primary hypertrophic osteoarthropathy. Rheumatol Int 2009;30(1):39-43.

9. Silveira LH, Martinez-Lavin M, Pineda C, Fonseca MC, Navarro C, Nava A. Vascular endothelial growth factor and hypertrophic osteoarthropathy. Clin Exp Rheumatol 2000;18: 57-62.

10. Jajic I, Jajic Z. Prevalence of primary hypertrophic osteoarthropathy in selected population. Clin Exp Rheumatol 1992;10:73.

11. Rastogi R, Suma GN, Prakash R, Rastogi UC, Bhargava S, Rastogi $\mathrm{V}$, et al. Pachydermoperiostosis or primary hypertrophic osteoarthropathy: a rare clinicoradiologic case. Indian J Radiol Imaging 2009;19(2):123-6.

12. Okten A, Mungan I, Kalyoncu M, Orbak Z. Two cases with pachydermoperiostosis and discussion of tamoxifen citrate treatment for arthralgia. Clin Rheumatol 2007; 26: 8-11.

13. Latos-Bielenska A, Marik I, Kuklik M, Materna-KirylukA, Povysil C, Kozlowski K. Pachydermoperiostosis-critical analysis with report of five unusual cases. Eur J Pediatr 2007;166:1237-43.

14. Athappan G, Unnikrishnan A, Chengat V, Chandraprakasam S, Arthanareeswaran V, Muthukrishnan S, et al. Touraine Solente Gole syndrome: the disease and associated tongue fissuring. Rheumatol Int 2009;29:1091-3.

15. Ghosn S, Uthman I, Dahdah M, Kibbi AG, Rubeiz N. Treatment of pachydermoperiostosis pachydermia with botulinum toxin type A. J Am Acad Dermatol 2010;63:1036-41.

16 Nelson AM, Zhao W, Gilliland KL, Zaenglein AL, Liu W, Thiboutot DM. Neutrophil gelatinase-associated lipocalin mediates 13-cis retinoic acid-induced apoptosis of human sebaceous gland cells. J Clin Invest 2008;118(4):1468-78.

17. Balmer JE, Blomhoff R. Gene expression regulation by retinoic acid. J Lipid Res 2000;43:1773-808.

18. da Costa VF, de Magalhães Souza Fialho SC, Zimmermann AF, Neves FS, Werner de Castro GR, Pereira IA. Infliximab treatment 
in pachydermoperiostosis. J Clin Rheumatol 2010;16(4):183-4. 19. George L, Sachithanandam K, Gupta A, Pulimood S. Frontal rhytidectomy as surgical treatment for pachydermoperiostosis. J Dermatolog Treat 2008;19(1):61-3.

20. Barraud-Klenovsek MM, Lübbe J, Burg G. Primary digital clubbing associated with palmoplantar keratoderma. Dermatology 1997;194(3):302-5.

21. Perić-Hajzler Z, Kandolf-Sekulović L, Zolotarevski L. Psoriatic onycho-pachydermo-periostitis. Serb J Dermatol Venereol 2010;2(2):54-8.

\section{Kongenitalna primarna pahidermoperiostoza udružena sa strijatnom keratodermijom - prikaz slučaja}

\section{Sažetak}

Uvod. Pahidermoperiostoza (PDP) predstavlja heterogeni sindrom za koji su karakteristične hipertrofične promene prvenstveno kože i kostiju ekstremiteta: pahidermija, klabing (clubbing) prstiju šaka i stopala i hipertrofična osteoartropatija. Primarna pahidermoperiostoza - sinonim Turen-Solent-Goleov sindrom (Touraine-Solente-Golé) (PPDP), ili primarna hipertrofična osteoartropatija (PHO), redak je nasledni poremećaj i predstavlja jedan od dva tipa hipertrofične osteoartropatije.

Za razliku od PPDP, sekundarna pahidermoperiostoza (sinonim sekundarna hipertrofična osteoartropatija SHO) javlja se u sklopu teških bolesti pluća (karcinom, bronhiektazije, apsces), pleuralnog mezotelioma, ili karcinoma timusa, ezofagusa ili želuca.

Primarna pahidermoperiostoza (PPDP) ili primarna hipertrofična osteoartropatija (PHO) redak je genetski poremećaj koji pogađa i kosti i kožu, sa nesigurnim načinom genetskog prenosa (autozomnodominantnim ali i autozomnorecesivnim), bez sigurnih dokaza o $\mathrm{X}$-hromozom vezanom nasleđivanju. Primarni genetski defekt kod ove bolesti je 2008. godine mapiran na 4q33-q34.15 pri čemu je identifikovna mutacija na genu HPGD koji kodira hidroksiprostaglandindehidrogenazu, glavni enzim degradacije prostaglandina. Jedna od glavnih karakteristika bolesti je uglavnom pahidermija (zadebljanje kože), upala pokosnice (prekomerno formiranja kosti) i tzv. klabing (oticanje tkiva sa gubitkom normalnog ugla između noktiju i nokatnog ležišta), sa idiopatskim akromegaloidnim promenama udruženim sa hipertrofičnom osteoartropatijom.Češće obolevaju muškarci.

Prikaz slučaja. Bolesnica starosti 55 godina, sa dugogodišnjiim prisustvom maljičastih prstiju i dijagnozom kongenitalne pahidermoperiostoze, koju je postavio fizijatar na osnovu ogovarajućih RTG snimaka još u detinjstvu, prvi put nam se javila 2011. godine; nije se do tada ozbiljnije lečila i ispitivala. Na prijemu je imala bolove u mišičima i zglobovima posebno u predelu malih zglobova šaka i stopala, promene na noktima prstiju stopala i nemogućnost stojanja na ravnoj podlozi, što je primoravalo da nosi samo obuću sa potpeticama. Primetila je tokom poslednjih desetak godina žućkaste deblje naslage na dlanovima i stopalima sa oštećenjem noktiju i deformitetima na prstima šaka i stopala. Takođe, imala je i otežan hod i osećaj bolova u zglobovima kolena, stopala, duž lumbosakralne kičme. Na osnovu priložene dokumentacije došlo se do podatka da je operisala benigne tumore na obe dojke 2003. godine, da se od tada redovno kontrolisala na 6 meseci kod onkologa; iz leve dojke odstranjen je intraduktalni papilom, a iz desne dojke aterom. Tokom narednih kontrola kod onkologa indikovano je odstranjenje novih tumorskih formacija na obe dojke, te je nakon snimanja magnetnom rezonanicijom i histopatološke analize postavljena dijagnoza fibromikrocistične displazije/adenoze, bez prisusustva ekspanzivnih promena i indikovane šestomesečne kontrole kod onkologa.

$\mathrm{Na}$ osnovu priložene dokumentacije takođe se saznalo da je 2008. godine odstranjena tumorska promena na dlanu desne šake koja je po patohistološkoj analizi odgovarala intradermalnom pigmentnom nevusu i siringomu. Zbog redukovane pasivne i aktivne pokretljivosti desne šake u celini, tada je indikovan i elektromiografski pregled desne ruke: lezija aksonskog tipa srednjeg do težeg stepena mišića C8, Th1 miotoma desnostrano, bez znakova aktuelizacije, što odgovara radikularnom sindromu. Pomoću RTG pregleda utvrđena je difuzna osteoporoza šaka, stopala i kolenih zglobova. Na osnovu merenja mineralne gustine kostiju (BMD) aparatom DEXA (eng. Dual Energy $\mathrm{X}$-ray), isključena je osteoporoza kičmenog stuba.

Iz porodične anamneze saznalo se da je očeva mati bolovala od „kostobolje“ sa promenama i tegobama koije su slične njenim, a da je otac umro od infarkta miokarda. $\mathrm{Na}$ prvom pregledu, objektivni fizički nalaz je pokazao da je bolesnica bila u dobrom opštem stanju, ali teško pokretna. Relevantni zaključci su ograničeni na kožu dlanova i tabana, prste i nokte, kao i kosti i zglobove 
na rukama i nogama: hiperkeratoza na dlanovima šaka i tabanima sa kliničkom slikom palmoplantarne keratodermije strijatnog tipa; znaci osteoartropatije hipertrofičnog tipa na prstima šaka sa slikom maljičastih prstiju; subungvalna hiperkeratoza na noktima stopala i šaka sa zadebljalim delom, distrofičnim nokatnim pločama žutomrke boje sa pojavom slike onihogripoze - kandžasti nokti; ingvinalna folikularna hiperkeratoza; keratotična i zadebljala koža oko Ahilovih tetiva i na skočnim zglobovima sa otokom skočnih zglobova.

Laboratorijski i drugi nalazi. Imala je abnormalne nalaze: sedimentacija $44 / 74 \mathrm{~mm} / \mathrm{h}$, broj eritrocita 3,19 x $10^{12} / \mathrm{L}$, hemoglobin: $10,5 \mathrm{~g} / \mathrm{L}$, osteokalcin: $54,3 \mathrm{ng} /$ $\mathrm{ml}$ (normalno 12-41ng/ml), crossLaps: $572 \mathrm{pg} / \mathrm{ml}$ (normalno 162-436 pg/ml). CEA karcinoembrioni antigen $9,7 \mathrm{ng} / \mathrm{ml}$ (normalno $<5,0 \mathrm{ng} / \mathrm{ml}$ ).

RTG snimak šaka i stopala i dugih kostiju: Izražena difuzna osteoporoza snimljenih koštanih struktura. Radiografija šaka: obostrano prisutno suženje proksimalnih interfalangealnih zglobnih prostora, izraženije na III, IV i V prstu desno, kao i na V prstu levo; izrazito suženje svih distalnih interfalangealnih zglobnih prostora, uz subluksaciju distalne falange $\mathrm{V}$ prsta desno; na svim prstima pisutna je akroosteoliza distalnih falangi, uz gotovo potpunu lizu distalne falange V prsta leve šake; prisutan otok okolnih mekih tkiva batičasti prsti. Radiografija stopala: obostrano prisutno suženje talokruralnog zgloba kao i metatarzofalangealnih zglobnih prostora I prsta; na svim prstima je prisutna akroosteoliza distalnih falangi, uz gotovo potpunu lizu distalne falange V, III prsta levog stopala, kao i III, IV i V prsta desno; obostrana periostalna reakcija na kalkaneusu, I metatarzalnoj kosti, izraženije desno, u vidu grubih egzostoza na distalnim glavicama I metatarzalne kosti oba stopala; spina kalkanei obostrano u projekciji plantarne aponeuroze i Ahilove tetive, masivnije desno. Rtg snimak dugih kostiju: obostrana periostalna reakcija na tibiji, fibuli.

RTG snimak kolena i dugih kostiju: izražena difuzna osteoporoza snimljeih koštanih struktura, obostrano prisutno asimetrično suženje zglobnog prostora tibiofemoranlnog zgloba; periostalne reakcije oba femura i snimkom obuhvaćene tibije i fibule; kalcifikacije u zatkolenim jamama; suženja patelofemoralnog zgloba obostrano.

Mmamografija i UZ dojku: promene odgovaraju fibrocistično izmenjenim dojkama

Rtg srca i pluća u PA pravcu: uredan.

Rtg gastroduodenuma: uredan.

UZ gornjeg abdomena: znaci polipoze i holesteroloze holeciste. Uterus miomatozus je uzgredan nalaz. Nalaz na jetri, pankreasu, bubrezima uredan.

CT toraksa nativno: uredan.

Dupleks sken vena i arterija donjih ekstremiteta: uredan nalaz na arterijama uz nalaz na venama, jedino nešto naglašenijeg Koketovog (Cockett) perforatora levo; u proksimalnom delu natkolenice, femoralno obostrano su vidljivi po jedan uvećan limfni nodus; evidentan je otok mekih tkiva distalno potkoleno, izraženije levo.

Histološki nalaz biopsije sa keratodermijskih promena na dlanovima šaka (tenar leve šake od 27.05. 2011. PH nalaz br.13072/11): epidermis je naglašeno hiperkeratotičan, prominentnog granularnog sloja, izduženih epidermalnih prečki; papilarni dermis je umereno edematozan; kolagena vlakna su grublja i demis je blago povećane debljine; u supkutanom masnom tkivu septa su naglašena i deblja; znojne žlezde su pravilne. Zaključak: promene u dermisu i subdermisu odgovaraju pahidermoperiostozi.

Specijalističke konsultacije: ORL, stomatolog, ginekolog, gastroenterolog, kardiolog, oftalmolog, pulmolog, fizijatar

Radiolog: na osnovu RTG pregleda skeleta, nađene promene na skeletu predominantno na dugim kostima, šakama i stopalima definišu izraženu formu pahidermoperistoze.

Fizijatar: Dolazi u obzir prepisivanje ortopedske obuće po meri sa povišicom. Postoji posturalni disbalans u sklopu osnovne bolesti, maljičasti prsti sa očuvanom funkcijom. Skolioza T4L, desna noga duža, desni kuk višlje postavljen, kontraktura desnog kolena, otoci potkolenica obe noge. Hod izmenjen.

Terapija. Predloženu terapiju sistemskim i lokalnim retinoidima pacijentkinja je odbila. Nakon što su isključeni mogući hronični ili maligni uzroci za sekundarnu hipertrofičnu osteoartropatiju, u terapiju je, pored NSAID i lokalne terapije keratoliticima, uključen tamoksifen (prepisao ginekolog), antiestrogeni lek koji bi mogao biti koristan u tretmanu cistične fibroze dojke i prevenciji karcinogeneze.

Diskusija. Primarna pahidermoperiostoza (PPDP) ili primarni oblik hipertrofične osteoartropatije (PHO), predstavlja retku naslednu bolest za koju je karakteristična trijada: maljičasti prsti na šakama i palčevima stopala, periostoza i pahidermija, kao i povišen nivo prostaglandina E2 (PGE2), što se može smatrati posledicom delovanja citokina na tkiva i krvne sudove. Kod PHO se ova dejstva povezuju sa pojavama hiperhidroze, akroosteolize, pahidermije, periostoze i artritisa. PGE2 može uticati na aktivnost osteoblasta i osteoklasta (odnosno izgradnju i osteoklaziju koštanog tkiva). Iz ovih razloga se akroosteoliza i periostalno 
obrazovanje kostiju objašnjavaju dejstvom PGE2. Štaviše, PGE2 ima vazodilatorne efekte, što je u skladu sa produženom lokalnom vazodilatacijom prisutnom u maljičastim prstima. Osim povišenog nivoa PGE2, studije o bolesnicima sa PDP pokazale su i povećane nivoe u plazmi nekoliko drugih mdijatora, kao što su Von Vilebrandov (Von Willebrand) faktor i vaskularni endotelni faktor rasta (VEGF). Ovi medijatori bi mogli imati značajnu ulogu u progresiji i širenju PDP (1). Za razliku od HPGD mutacija, nije do sada utvrđeno postojanje mutacija na genima koji kodiraju sintezu navedenih faktora.

$\mathrm{Na}$ osnovu fenotipske ekspresije, razlikuju se tri podtipa PDP: 1) kompletan fenotip, koji u 40\% slučajeva može uključivati sve do sada opisane simptome i znake PDP, ali obavezno pahidermiju, periostozu i maljičaste prste, što je puni fenotip bolesti; 2) Nepotpuni fenotip se javlja u $54 \%$ slučajeva, a karakterišu ga uglavnom koštane i skeletne promene, dok je pahidermija slabije izražena; 3 ) frusta fenotip javlja se u samo $6 \%$ slučajeva; kliničkom slikom dominiraju promene na koži sa manje izraženim skeletnim promenama i ograničenom periostozom (1). Nepoznat je uzrok nastanka ovako različitih formi bolesti (1). U našem slučaju se radilo o kompletnom fenotipski ispoljenom obliku bolesti udruženom sa palmoplantarnom keratodermijom strijatnog tipa. U 25-38\% slučajeva, pacijenti imaju familijarnu pojavu PDP (4), što nije siguran podatak u našem slučaju. Autozomnodominantni model nasleđivanja, sa izrazitom penetrantnošću i varijabilnošću, potvrđen je kod oko polovine porodica sa nepotpunim oblikom bolesti (1). Nekoliko porodica, sa poznatim autozomno recesivnim modelom nasleđivanja, imalo je kompletno fenotipski ispoljen oblik bolesti sa izraženim koštano-skeletnim i kožnim oblikom bolesti. $S$ obzirom na postojanje samo anamnestičkih podataka o pojavi oboljenja samo kod očeve majke, i naša bolesnica mogla se ubrojati u ovu grupu sa recesivnim modelom nasleđivanja PDP.

Biopsija kože predstavlja još jedan način da se dijagnostikuje PDP. Histologija otkriva kutanu sklerozu, hijalinozu, perivaskularni infiltrat limfoidnih ćelija; takođe mogu biti prisutni hipertrofija kolagena i epidermisa i epidermalnih adneksa, kao i povećanje nivoa kiselih mukopolisaharida. Međutim, to nije apsolutno specifičan nalaz, jer se i kod drugih bolesti mogu u koži ispoljiti slične promene kao kod PDP, npr. kod miksedema, hipotireoze, akromegalije. Međutim, biopsija kože pomaže postavljanju dijagnoze PDP u nejasnim slučajevima. Histološki, analiza kože uzete sa keratodermijskih promena na dlanovima šaka kod naše pacijentkinje, zajedno sa promenama u dermisu i subdermisu, koje odgovaraju pahidermoperiostozi, potvrdila je kliničku dijagnozu palmoplantarne keratodermije u sklopu pahidermoperistoze.

Radi postavljanja dijagnoze PPDP, često moraju biti isključene druge bolesti. $\mathrm{Na}$ primer, isključuje se sekundarna hipertrofična osteoartropatija u sklopu kardiovaskularnih, plućnih, jetrenih, crevnih i medijastinalnih bolesti. Radi postavljanja diferencijalne dijagnoze, potrebna je detaljna hormonalna pretraga (npr. tirrotropni i nivo hormona rasta) što je je sprovedeno kod naše bolesnice. U našem slučaju isključene su endokrinološke abnormalnosti štitne žlezde.

Kada govorimo o toku i prognozi bolesti, PPDP obično napreduje tokom 5 do 20 godina, dok tok ne postane stabilan. Očekivano trajanje života može biti nepromenjeno, bez obzira na to što bolesnici imaju mnogo funkcionalnih i estetskih komplikacija, uključujući ograničeno kretanje, neurološke manifestacije i „lavlje lice" sa naborima (facies leontina).

Konvencionalna terapija PPDP je u osnovi simptomatska, najčešće se bazira na nesteroidnimantiinflamatornim lekovima (NSAIL) i kortikosteroidima koji se daju sa ciljem smanjenja upale i bola. NSAIL inhibicijom enzima ciklooksigenaze smanjuju nivo prostaglandina. Drugi lekovi se koriste kod bolesnika sa PPDP sa ciljem delovanja na kosti i promene na koži. Retinoidi se koriste prvenstveno za poboljšanje kožnih promena. Infliksimab, biološki inhibitor faktora tumorske nekroze alfa (TNFalfa) može biti efikasan u resorpciji novostvorene kosti. Hirurški tretman služi za poboljšanje estetskih i funkcionalnih sposobnosti obolelih.

Kada je palmoplantarna strijatna keratodermija u pitanju, do sada nismo našli, u nama dostupnoj literaturi, njenu udruženost sa PPDP. Baro-Klenovsek (BarraudKlenovsek) objavili su slučaj 30-godišnje žene sa palmoplantarnom keratodermijom i maljičastim prstima 1997. godine. Nedavno, Perić i saradnici, objavili su slučaj pahidermoperiostitisa kod bolesnika sa psorijazom.

Zaključak. U radu je prikazan kongenitalni oblik pahidermoperiostoze kod ženske osobe kod koje se tokom života razvila strijatna keratoderma. Prema nama dostupnoj literaturi, ovo bi bio prvi objavljeni slučaj udružene pojave ove dve dermatoze.

\section{Ključne reči}

Primarna hipertrofična osteoartropatija; Palmoplantarna keratodermija; Dijagnoza; Znaci i simptomi; Komorbiditet 